\title{
Portage of Bacteria Responsible of Foodborne Illness in Scholarly Canteens (Republic of Benin)
}

\author{
Honoré Sourou Bankolé, ${ }^{1,2}$ Tossou Jacques Dougnon ${ }^{1}$, Patrick Aléodjrodo Edorh ${ }^{3,4}$, \\ Tamègnon Victorien Dougnon ${ }^{1,4^{*}}$, Magloire Legonou ${ }^{2}$, Jean Robert Klotoé ${ }^{1}$, Frédéric Loko ${ }^{1,2}$ \\ ${ }^{1}$ Polytechnic School of Abomey-Calavi, Research Laboratory in Applied Biology, \\ University of Abomey-Calavi, Cotonou, Benin \\ ${ }^{2}$ Laboratory of Food Microbiology, Ministry of Health, Cotonou, Benin \\ ${ }^{3}$ Faculty of Science and Technology, Department of Biochemistry and Cellular Biology, \\ University of Abomey-Calavi (UAC), Cotonou, Benin \\ ${ }^{4}$ Interfaculty Center of Formation and Research in Environment for the Sustainable Development, \\ Laboratory of Toxicology and Environmental Health, University of Abomey-Calavi (UAC), Cotonou, Benin \\ Email: victorien88@hotmail.com
}

Received June 17, 2012; revised July 17, 2012; accepted July 26, 2012

\begin{abstract}
This study has determined the portage of bacteria responsible for foodborne illness in the school canteen staff. 336 samples taken on the nose, mouth and hands were collected. Microbiological analyses were realized and several pathogenic bacterial strains were isolated from the vendors: Staphylococcus aureus (26/122), sulphite-reducing clostridia (14/122) and Escherichia coli (10/122). The food vendors in the school canteen may be the vectors of germs that cause food poisoning among young students.
\end{abstract}

Keywords: Portage; Bacteria; Food; Escherichia coli; Disease

\section{Introduction}

Foodborne diseases are, by the world, a major public health problem. Although most often manifested by diarrhea with an estimated three million deaths a year in children under five years of age, they have other serious consequences such as kidney and liver failure, brain disorders and neurological disorders and death $[1,2]$.

According to WHO, almost one third of people in developed countries have an infection caused by foods. In less developed countries, diarrheal diseases transmitted through water and foods are major causes of morbidity and mortality. They cause about 2.2 million deaths per year especially in children [3].

In Benin, the number of cases of diarrheal diseases is estimated at 309.944 with 331 deaths per year [4].

Deeply concerned by this situation, the $53^{\text {rd }}$ World Health Assembly adopted a resolution in May 2000 to develop a global strategy to reduce the burden of foodborne illness. Estimates of the overall number of episodes of foodborne illness are helpful for allocating resources and prioritizing interventions. However, arriving at these estimates is challenging because food may be-

*Corresponding author. come contaminated by many agents (a variety of bacteria, viruses, parasites, and chemicals), transmission can occur by nonfood mechanisms (e.g., contact with animals or consumption of contaminated water), the proportion of disease transmitted by food differs by pathogen and by host factors (age and immunity), and only a small proportion of illnesses are confirmed by laboratory testing and reported to public health agencies [5].

Laboratory-based surveillance provides crucial information for assessing foodborne disease trends. However, because only a small proportion of illnesses are diagnosed and reported, periodic assessments of total episodes of illness are also needed [5]. Several countries have conducted prospective population-based or crosssectional studies to supplement surveillance and estimate the overall number of foodborne illnesses [6]. In 2007, the World Health Organization launched an initiative to estimate the global burden of foodborne diseases [7].

Most often, when cases of foodborne illness are reported, only consumed foods are involved. The catering staff which is the more in contact with food than others is not usually investigated [8].

This observation justifies the present study entitled "Portage of bacteria responsible of foodborne illness in restaurants and school canteens”. It aims to determine the 
involvement of catering staff in food contamination.

\section{Materials and Methods}

\subsection{Material}

Biological material was composed of 336 samples obtained by swabbing the nostrils, mouth and hands. Petri dishes, swabs, hemolysis tubes, tubes, autoclaves, microscopes, refrigerators, lyophilized rabbit plasma, hydrogen peroxide, Kovacs reagent, hard oxidase, hydrochloric acid, gentian violet, fuchsin, lugol, Eosin Methylene Blue agar, Chapman, peptone water buffered agar, Hektoen, etc. have been used among others.

\subsection{Methods}

A cross-sectional study was conducted from November 2011 to June 2012. Samples were collected from nine primary schools and three colleges randomly selected in the $8^{\text {th }}, 9^{\text {th }}$ and $13^{\text {th }}$ districts of Cotonou.

The study population was composed of 112 women in canteens of primary schools and colleges. Nasal swabs, mouth and hands were performed by swabbing. Ethical approval has been received and only volunteers were included in the study. All women underwent a medical examination and only those who were visibly in good health (no flu, cough) were allowed to be taken.

For nasal swabs, we left swab from its package, tilt the patient's head slightly back, inserted the swab into the nostril, rotated it and print the swab in a tube containing $0.5 \mathrm{ml}$ buffered peptone water in compliance with aseptic conditions.

About mouth swabs, the swab must be introduced into the mouth of the patient. After rubbing teeth and tongue, print the swab into a tube containing $0.5 \mathrm{ml}$ buffered peptone water.

About hands samples, we left the swab from its package, moisten it with sterile distilled water and printed it into a tube containing $0.5 \mathrm{ml}$ buffered peptone water.

All samples were transported to the laboratory in a cooler at $4^{\circ} \mathrm{C}$. Microbiological analyzes were performed on five days:

\subsection{First day}

\subsubsection{Fresh State}

Two drops of each of the resulting suspensions were deposited on a slide and covered with a coverslip. The preparation thus obtained was observed under an optical microscope with $\times 40$ objective.

\subsubsection{Colored State}

A smear was made from each suspension obtained, Gram stained and observed microscopically at the immersion objective.

\subsubsection{Culture}

The culture media were selected and seeded based on the results of microscopic observation. The culture media were incubated seeded according to culture condition of suspected bacteria.

\subsubsection{Pre-Enrichment for the Isolation of Salmonella and Shigella}

The suspensions obtained in peptone water were incubated in an oven at $37^{\circ} \mathrm{C}$ for 18 hours.

\subsection{Second Day}

\subsubsection{Reading}

All culture media seeded the previous day were reviewed. The colonies on selective agar media were counted. Microscopic observation of control was performed on each culture medium.

\subsubsection{Identification}

The isolated bacteria were identified based on biochemical characteristics obtained through the use of the API 20 $\mathrm{E}$ and some biochemical tests: looking for catalase, cytochrome oxidase research and research of free staphylocoagulase. These tests were performed following the methodology adopted by [9].

\subsubsection{Enrichment of Salmonella and Shigella}

A volume of $0.5 \mathrm{ml}$ of the culture pre-enrichment was introduced in $4 \mathrm{ml}$ of Rappaport broth. The whole was incubated at $37^{\circ} \mathrm{C}$ for 24 hours.

\subsection{Day Three}

\subsubsection{Reading Galleries}

Reading the API $20 \mathrm{E}$ was conducted in accordance with the methodology adopted by [9].

\subsubsection{Isolation of Salmonella and Shigella}

SS and Hektoen agars were inoculated from the enrichment broth.

\subsection{Day Four}

Api 20 E galleries were inoculated from SS and Hektoen agar with bacterial colonies.

\subsection{Fifth Day}

It was devoted to reading galleries and identification of a possible presence of bacteria.

\section{Statistical Analyses}

The prevalence of germs found was calculated. Microsoft Excel 2010 and XL Stat 2011 were used as software. 


\section{Results}

\subsection{Point of Bacterial Strains Isolated during the Study}

About bacterial strains isolated during this study, the results are on Figure 1. On manipulated samples, 122 bacterial strains were isolated and identified. Gram-positive cocci are leading with $47.54 \%$ followed by $29.51 \%$ with enterobacteria.

Specifically, among the enterobacteriaceae, Klebsiella pneumoniae is the most isolated (38. 89\%) while the only non-enterobacteriaceae isolated microorganism is Pseudomonas aeruginosa. Among the Gram-positive cocci, the most isolated is Staphylococcus aureus (44.83\%). Other bacteria most frequently isolated are sulphite-reducing clostridia (Figure 2).

\subsection{Point of Bacterial Strains Isolated from the Mouths of Vendors}

About the distribution of bacterial strains isolated from the mouths of vendors, the results are as shown in Figure 3. 33 bacterial strains were isolated and identified. Grampositive cocci are leading with $54.55 \%$ followed by 30.30\%. of Enterobacteriaceae.

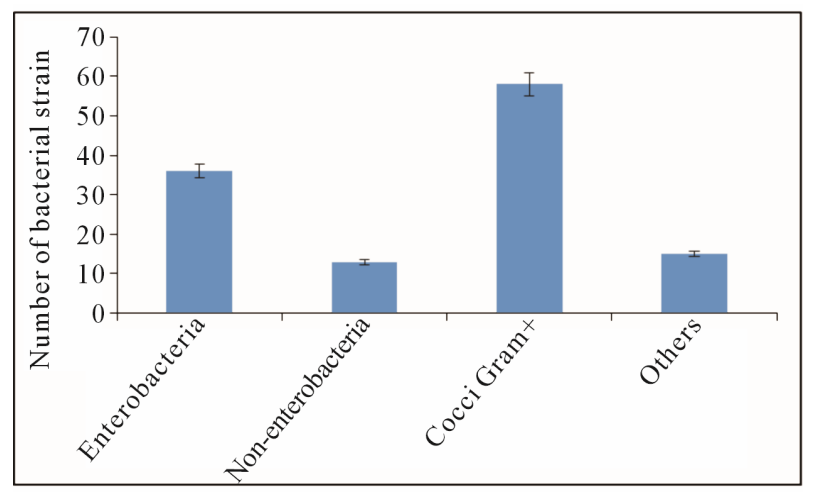

Figure 1. Number of bacterial strains isolated during this study.

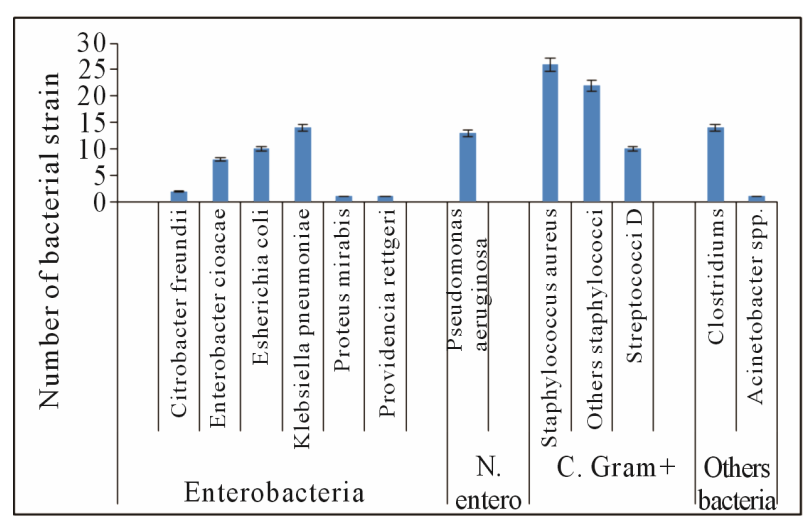

Figure 2. Point of isolated bacterial species.

\subsection{Point of Bacterial Strains Isolated from the Hands of Vendors}

About the distribution of bacterial strains isolated from the hands of vendors, the results are presented in Figure 4. 37 bacterial strains were isolated and identified. Enterobacteriaceae are leading with $45.95 \%$ followed by $24.32 \%$ with non-Enterobacteriaceae.

\subsection{Point of Bacterial Strains Isolated from the Nose of Vendors}

Relative to the nose of the vendors, the results are presented in Figure 5. 52 bacterial strains were isolated and identified. Gram-positive cocci are leading with $64.70 \%$ followed by $17.65 \%$ with enterobacteria.

\section{Discussion}

This study contribute to the determination of the involvement of catering staff in schools and colleges about food contamination. Control of all aspects of quality and food security is possible only if the operator is trained and aware. Most vendors were educated. [10] made the same remark in Ghana.

The results of microbiological analyzes revealed the

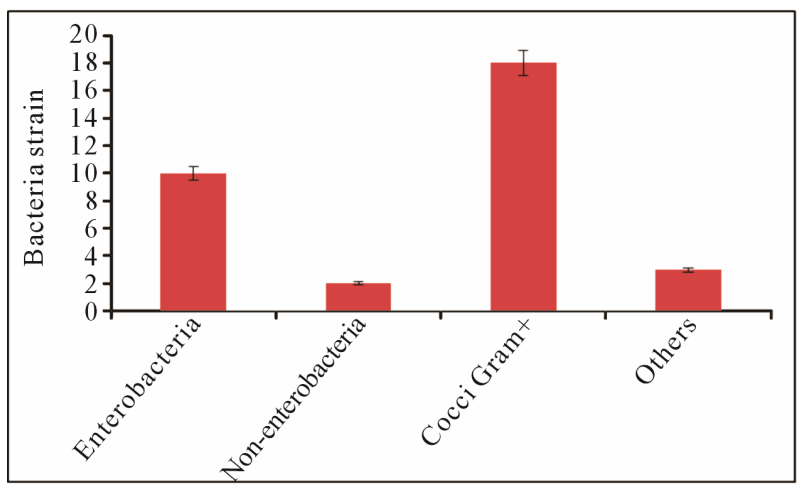

Figure 3. Number of bacterial strains isolated from the mouths of vendors.

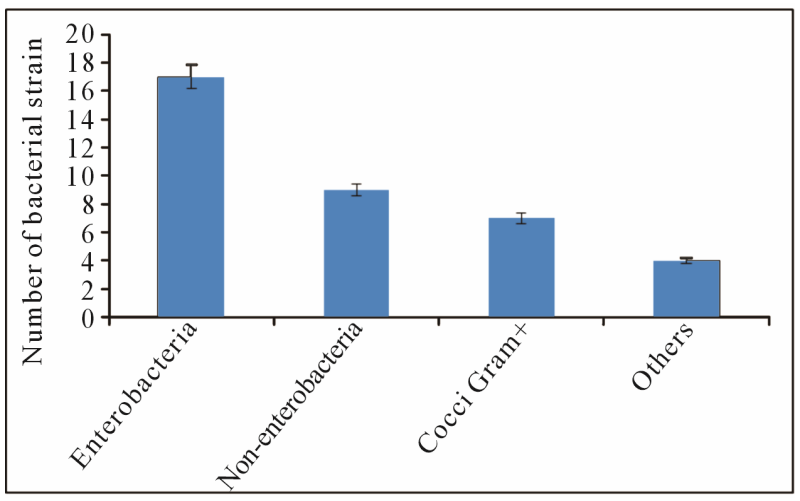

Figure 4. Number of bacterial strains isolated from the hands of vendors. 


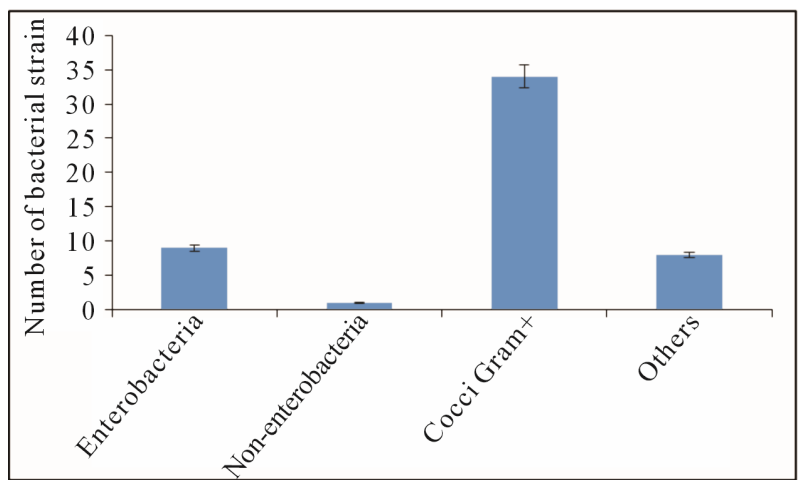

Figure 5. Number of bacterial strains isolated from the nose of vendors.

presence of microorganisms involved in food poisoning (Staphylococcus aureus, Escherichia coli and sulphitereducing clostridia); of spoilage microorganisms (Pseudomonas aeruginosa) and microorganisms from testifying faecal contamination (Klebsiella pneumoniae, Citrobacter freundii, E. cloacae, P. mirabis, Providencia rettgeri, Acinetobacter spp and streptococcus D). A study in USA showed the same conclusions [11]. It has been investigated an outbreak in which a food handler, food specimen, and three ill patrons were culture positive for the same toxin-producing strain of Staphylococcus aureus [11]. In the hands of vendors, the predominant microorganism is Klebsiella pneumoniae. The presence of this organism is soil-borne or fecal [12]. This raises the problem of compliance with the rules of hygiene by vendors in Cotonou.

[13] reported that the role of hand-range transmission of bacteria of fecal origin is demonstrated. This could be explained by the lack of regular monitoring and awareness of women.

The species Staphyloccoccus aureus were isolated in $18 \%$ of samples from the nose of the vendors. Although the nasal cavity is a reservoir of this organism and that $30 \%$ of adults harbor this organism permanently, $50 \%$ intermittently, the immaturity of about $15 \%$ of the vendors induced that the risk of contamination could be high [9]. Indeed, from the nose, the germ can spread to the skin, hands and the environment. A survey conducted by [14] showed that the main sources of microorganisms in food are animal and feces [15]. In addition, Staphylococcus aureus causes food-poisoning by the production of one or more heat-stable extracellular toxins, which are wholly responsible for the symptoms of the disease. Foods most often incriminated in staphylococcal foodborne disease include cooked meat, fish, poultry, bakery foods (especially those with cream or custard fillings), dairy produce, fruit, vegetables, and salads [16]. Methods of food handling by vendors from preparation to the sale do not guarantee the elimination of contamination and microbial growth potential.
[17] showed that Staphylococcus aureus and Bacillus cereus were often highlighted in food samples. Given the fact that the spread of staphylococci in the environment is possible from the nasal cavity of healthy carriers and patients [14], we can assess the risks to students, food consumers manipulated by these women.

Foods favor the growth of staphylococci and toxin production are protein-rich products and products with a $\mathrm{pH}$ close to neutral [18]. The majority of vendors handling food are favorable to the growth of staphylococci. Under these conditions, considering that 20 minutes is enough for one generation [18], if the food is already prepared at 7 o'clock in the morning and put on sale at 10 a.m, a microorganism that would contaminate the food immediately after preparation due to poor hygiene practice, would have had time to multiply and give according to the formula:

$$
X_{n}=X_{o} \cdot 2^{n}
$$

$X_{n}=1 \times 2^{9}$ bacteria.

$1 \times 2^{9}$ bacteria is equivalent to 512 bacteria so about 5 , $10^{2}$ bacteria. As shown, a sneeze could propel billions of microorganisms in the environment, the probability of having $10^{6}$ to $10^{10}$ microorganisms per gram of food is great, which proves that children in schools are every day at risk of food poisoning linked to the status of porting vendors.

Following this study, were isolated and identified in the food vendors in school canteens bacterial strains of food poisoning, Staphylococcus aureus, Escherichia coli and sulphite-reducing clostridia; of food spoilage bacteria (Pseudomonas aeruginosa) and bacteria indicating fecal contamination, Klebsiella pneumoniae, Citrobacter freundii, Enterobacter cloacae, Proteus mirabis, Providencia rettgeri, Acinetobacter spp and streptococcus D. This situation poses not only a problem of hygienic quality of food sold by the women but also a potential risk of foodborne illness among students.

\section{Acknowledgements}

We thank all the staff of the National Laboratory of Health Ministry/Benin who works every day for the wellbeing of people.

\section{REFERENCES}

[1] OMS, "Une Alimentation à Moindre Risque pour une Meilleure Santé,” In La Stratégie Mondiale de l’OMS Pour la Salubrité des Aliments, Genève (Suisse), 2001, pp. 20-22.

[2] O. Cerf, M. Eliaszewicz and C. Lahellec, "Les Maladies Infectieuses d'Origine Alimentaire,” Académie des Sciences, la Maîtrise des Maladies Infectieuses, Edition edp Sciences, 2006, pp. 172-174. 
[3] I. Sanoui, K. L. Kam, L. Sangaré and A. Tougouma, "Diarrhées Aiguës de l'Enfant: Aspects Epidémiologiques, Cliniques et Evolutifs en Milieu Hospitalier Pédiatrique à Ouagadougou," Médecine d'Afrique Noire, Vol. 46, No. 1, 1999, pp. 20-26.

[4] Ministère de la Santé Publique, "Distribution des cas de Maladies à Potentiel Epidémique par Zone Sanitaire en 2006 au Bénin, SNIGS-MS,” Annuaire des Statistiques Sanitaires, Rapport Epidémiologique Annuel au Bénin, 2006.

[5] E. Scallan, R. M. Hoekstra, F. J. Angulo, R. V. Tauxe, M. A. Widdowson and S. L. Roy, "Foodborne Illness Acquired in the United States-Major Pathogens," Emerging Infectious Disease, Vol. 17, No. 1, 2011, pp. 7-15. doi:10.3201/eid1701.09-1101p1

[6] J. A. Flint, Y. T. Van Duynhoven, F. J. Angulo, S. M. DeLong, P. Braun and M. Kirk, "Estimating the Burden of Acute Gastroenteritis, Foodborne Disease, and Pathogens Commonly Transmitted by Food: An International Review," Clinical Infectious Diseases, Vol. 41, No. 5, 2005, pp. 698-704.

[7] T. Kuchenmuller, S. Hird, C. Stein, P. Kramarz, A. Nanda and A. H. Havelaar, "Estimating the Global Burden of Foodborne Diseases-A Collaborative Effort," Eurosurveillance, Vol. 14, No. 18, 2009, p. 19195.

[8] L. P. Kouadio, E. Atindehou and N. B. Ekra, "Etude de la Potabilité des Eaux de Boisson en Sachets Vendues aux Abords des Ecoles Primaires Publiques d'Abidjan,” Bulletin de la Société de Pathologie Exotique,Vol. 2, 1998, pp. 167-168.

[9] T. Badédji and R. M. Moussa, "Portage des Bactéries Responsables de Toxi-Infections Alimentaires Chez les Manipulateurs d'Aliments Dans les Cantines Scolaires,” Mémoire de DIT, Université d’Abomey-Calavi, Bénin, 2008.

[10] P. Mensah, "Street Foods in Accra: How Safe Are They?" Bulletin of the World Health Organisation, Vol. 7, No. 80,
2002, pp. 546-554.

[11] F. J. Timothy, E. K. Molly, S. P. B. Susan and W. Michael, "An Outbreak of Community-Acquired Foodborne Illness Caused by Methicillin-Resistant Staphylococcus aureus,” Emerging Infectious Disease, Vol. 8, No. 1, 2002, pp. 82-84. doi:10.3201/eid0801.010174

[12] M. I. Mirabaud, "Entérobactéries à Bêta-Lactamases à Spectre Elargi En Pédiatrie,” Thèse de Doctorat en Médecine, Université de Genève, Suisse, 1996.

[13] C. Dosso and A. Kadio, "Place des Diarrhées Bactériennes Dans les Pays en Développement, Manuscrit n PF02,” Journée en hommage au Professeur A, Dodin, Abidjan, Côte d'Ivoire, 1998.

[14] B. China, Y. Ghafir and G. Daube, "Estimation Quantitative et Qualitative par Amplification Génétique de Bactéries Présentes Dans les Denrées Alimentaires,” Annales de Médecine Véterinaire, Vol. 147, 2002, pp. 99109.

[15] T. V. Dougnon, H. S. Bankolé, A. P. Edorh, T. J. Dougnon, M. Gouissi, A. Hounkpatin, S. Montcho, H. Azonhè, J. R. Klotoé and M. Boko, "Evaluation of the Microbiological Quality of the Leaves of Solanum macrocarpum L. Cultivated with the Chicken's Droppings and Water of Marsh in Cotonou (Republic of Benin)," International Journal of Biosciences, Vol. 2, No. 2, 2012, pp. 45-52.

[16] H. S. Tranter, "Foodborne Staphylococcal Illness," The Lancet, Vol. 336, No. 8722, 1990, pp. 1044-1046. doi:10.1016/0140-6736(90)92500-H

[17] M. R. El-Sherbeeny, "Microbiological Profile and Storage Temperatures of Egyptian Rice Dishes," Journal of Food Protection, Vol. 48, No. 1, 1985, pp. 39-43.

[18] M. Cornu and P. Rosset, “Appréciation Quantitative de la Croissance Bactérienne Potentielle à Partir de Profils Temps-Température," Bulletin de l'Académie Vétérinaire de France, Vol. 1, No. 157, 2004, pp. 93-100. 